\title{
Discrimination of Shark species by simple PCR of 5S rDNA repeats
}

\author{
Danillo Pinhal $^{1}$, Otto BF Gadig ${ }^{2}$, Adriane P Wasko ${ }^{3}$, Claudio Oliveira ${ }^{1}$, Ernesto Ron ${ }^{4}$, \\ Fausto Foresti ${ }^{1}$ and Cesar Martins ${ }^{1}$ \\ ${ }^{1}$ Departamento de Morfologia, Instituto de Biociências, Universidade Estadual Paulista, \\ Botucatu, SP, Brazil. \\ ${ }^{2}$ Campus Litoral Paulista, Universidade Estadual Paulista, São Vicente, SP, Brazil. \\ ${ }^{3}$ Departamento de Genética, Instituto de Biociências, Universidade Estadual Paulista, Botucatu, \\ SP, Brazil. \\ ${ }^{4}$ Escuela de Ciencias Aplicadas del Mar, Universidad de Oriente, Boca del Rio, Isla Margarita, \\ Nueva Esparta, Venezuela.
}

\begin{abstract}
Sharks are suffering from intensive exploitation by worldwide fisheries leading to a severe decline in several populations in the last decades. The lack of biological data on a species-specific basis, associated with a k-strategist life history make it difficult to correctly manage and conserve these animals. The aim of the present study was to develop a DNA-based procedure to discriminate shark species by means of a rapid, low cost and easily applicable PCR analysis based on $5 \mathrm{~S}$ rDNA repeat units amplification, in order to contribute conservation management of these animals. The generated agarose electrophoresis band patterns allowed to unequivocally distinguish eight shark species. The data showed for the first time that a simple PCR is able to discriminate elasmobranch species. The described $5 S$ rDNA PCR approach generated species-specific genetic markers that should find broad application in fishery management and trade of sharks and their subproducts.
\end{abstract}

Key words: Chondrichthyes, PCR, species identification, 5S rDNA, sharks.

Received: August 22, 2006; Accepted:April 18, 2007.

The large worldwide increase in elasmobranch fisheries over the past decade is due not only to the intentional catch of these animals but also a result of a massive elasmobranch "bycatch" during Teleostei fisheries, leading to an unprecedented exploitation pressure on many sharks and rays populations (Bonfil, 1994). In contrast to teleost fishes, several studies have shown that elasmobranchs are remarkably susceptible to population decline and/or population collaps due to exhaustive exploitation (Kotas et al., 1995; Vooren, 1997; Musick et al., 2000; Baum et al., 2003).

In a general context, elasmobranch stocks management is complex due to a lack of basic biological data for most species. Several recently published studies have provided a more accurate picture of the status of some populations (Simpfendorfer et al., 2000; Cortés, 2002; Baum et al., 2003; Baum and Myers, 2004), showing that the different life history parameters of each shark species result in a differential sensitivity to intensive exploitation (Heist and Gold, 1999; Castro et al., 1999). Thus, an efficient world-

Send correspondence to Cesar Martins. Departamento de Morfologia, Instituto de Biociências, Universidade Estadual Paulista, 18618-000 Botucatu, SP, Brazil. E-mail: cmartins @ ibb.unesp.br. wide management and conservation efforts will require fishery information on a species-specific basis. Nonetheless, this issue may not be easily achieved, due to the considerable difficulty of accurate species identification for several usually targeted species (Bonfil, 1994; Castro et al., 1999). The identification problem is exacerbated by the common fishery practice of removing the head, tail, and most fins from landed sharks while still at sea to reduce required storage space for the captured animals. This practice removes the major morphological identifying characters of the animals, making it difficult to precisely recognize species and, consequently, resulting in problems of proper management (Shivji et al., 2002).

The implementation of molecular biological techniques in marine forensic science has improved the development of accurate taxonomic identification of shark species by sampling biological tissues (Lavery, 1992; Heist and Gold, 1999). Several methods mainly based on protein separation by electrophoresis or high-performance liquid chromatography have been developed for species identification (Sotelo et al., 1993). In recent years, new DNA analyses have been finding their way into the identification of 
species, subspecies, populations, strains, hybrids and individuals. DNA amplification using the polymerase chain reaction (PCR) (Mullis and Faloona, 1987) has been used as a powerful alternative tool to protein electrophoresis, chromatography and immunological methods, due to its simplicity, specificity and sensitivity. DNA-based genetic markers, especially those related to important traits such as growth enhancement and viral and bacterial disease resistance, have been developed for aquaculture purposes primarily with the goal of improving fish stocks and strains. On the other hand, DNA markers also find application in conservation programs, specifically for stocks identification, breeding selection, analysis of loci segregation and quantitative traits, and for accessing species genetic variability (Martins et al., 2004).

In higher eukaryotes, the $5 \mathrm{~S}$ ribosomal DNA (5S rDNA) array consists of multiple copies of a highly conserved 120 base pairs (bp) coding sequence, separated from each other by a variable non-transcribed spacer (NTS) (Long and David, 1980) (Figure 1). The 5S rDNA represents a suitable candidate for PCR-based genetic studies due to several features: (i) head to tail organization of the 5S rDNA multigene family members; (ii) the NTS is flanked by the $5 \mathrm{~S}$ rRNA gene copies in the 5S rDNA tandem array, thus the PCR technology can be used in the isolation of the NTSs; (iii) the 5S rRNA gene is highly conserved even among distantly related species and, consequently, it is possible to isolate the $5 \mathrm{~S}$ rDNA repeats of one species based on the available sequence of another distantly related species with the use of PCR; (iv) repetitive units of the 5S rDNA do not exceed the length of PCR amplification range; (v) the isolation of the repeat units of $5 \mathrm{~S}$ rDNA can be obtained from DNA of poor quality and quantity due to their tandem nature and small size (Martins and Wasko, 2004).

Moreover, the distinct genome organization patterns of the 5 $\mathrm{S}$ rDNA tandem repeats have been also useful as genetic markers not only in evolutionary studies but also in practical approaches for the discrimination of fish species (Pendas et al., 1995; Sajdak et al., 1998; Céspedes et al., 1999; Asensio et al., 2001), even for species of the same genus (Perez and Garcia-Vázquez, 2004; Aranishi, 2005). Nonetheless, there are no data about the usefulness of the $5 \mathrm{~S}$ rDNA as genetic marker in the elasmobranch fish group.

Hence, the present work aimed to develop a simple and reliable DNA routine method for an accurate discrimi-

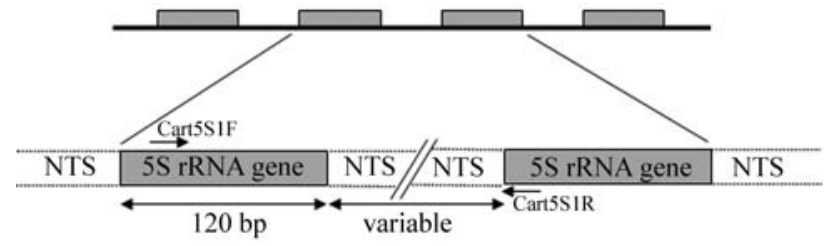

Figure 1 - Arrangement of higher eukaryotic 5S rRNA genes intercalated with non transcribed DNA segments (NTS). The primers Cart5S1F and Cart5S1R annealing regions are indicated. nation of diverse shark species based on simple PCR amplification and agarose gel electrophoresis analysis. For this purpose, 5S rDNA tandem repeats were evaluated to generate species-specific amplified fragment patterns on eight different sharks species, including closely related species of the genus Carcharhinus.

Sharks belonging to the Orders Carcharhiniformes and Lamniformes were collected from several Brazilian and Venezuelan coast sites: Sphyrna lewini and Isurus oxyrinchus from the municipality Ubatuba (São Paulo State, Brazil); Carcharhinus limbatus and Carcharhinus acronotus from the municipality Fortaleza (Ceará State, Brazil); Galeocerdo cuvier from the Espírito Santo State (Brazil); Alopias superciliosus from the oceanic area in the Southeast of Brazil; Carcharhinus leucas from the Bombinhas beach (Santa Catarina State, Brazil), and Carcharhinus obscurus from Isla Margarita (Venezuela). Five to ten samples of each species were evaluated for the analyses. Previous morphological species identification was realized on all shark samples. Species identification of some samples (C. acronotus, C. leucas, C. obscurus, $C$. limbatus, A. superciliosus, and I. oxyrinchus) was carried out using complete specimens that were not preserved due their large size. Small specimens of S. lewini and G. cuvier were preserved in the fish collection of the Laboratorio de Biologia e Genética de Peixes-UNESP, Botucatu, SP, and Instituto de Pesca, Santos, SP. The tissues were collected from specimens that were caught by commercial fisheries, or from frozen or ethanol preserved specimens. Genomic DNA was extracted from fin clip, gills and muscles according to Sambrook and Russell (2001). PCR amplifications of 5S rDNA repeats were performed as described by Martins and Galetti (2001) with some modifications. The primers, Cart5S1F (5'-CAC GCC CGA TCC CGT CCG ATC-3') and Cart5S1R (5'-CAG GCT AGT ATG GCC ATA GGC-3') (Figure 1) were designed based on the 5S rRNA gene sequence of the elasmobranchs Taeniura lymma (AY278251) (Rocco et al., 2005) and Scyliorhinus caniculus (M24954) (Wegnez et al., 1978). Each PCR reaction mixture contained 150 pmoles of each primer, approximately $20 \mathrm{ng}$ of genomic DNA, 1x Taq buffer, $200 \mu \mathrm{M}$ of dNTPs, and $2 \mathrm{U}$ of Taq polymerase (Invitrogen) in a final reaction volume of $25 \mu \mathrm{L}$. Cycling times were as follows: 5 min at $94{ }^{\circ} \mathrm{C} ; 35$ cycles of 1 min at $95^{\circ} \mathrm{C}$ (denaturation), $30 \mathrm{~s}$ at $55^{\circ} \mathrm{C}$ (annealing) and $45 \mathrm{~s}$ at $72^{\circ} \mathrm{C}$ (elongation); and a final extension step for $5 \mathrm{~min}$ at $72^{\circ} \mathrm{C}$. A negative control was also included to check for contamination. The PCR products were analyzed by running $3 \mu \mathrm{L}$ of each reaction on $1.25 \%(\mathrm{w} / \mathrm{v})$ agarose gels containing $1 \mathrm{x}$ TAE buffer (0.04 M TRIS-acetate and $1 \mathrm{mM}$ EDTA, pH 8.3) and compared with a standard DNA marker (1 kb Plus Ladder Invitrogen). Electrophoresis was carried out in $1 \mathrm{x}$ TAE buffer (90 min, $120 \mathrm{~V}$ and approximately $150 \mathrm{~mA}$ ) at room temperature. Fragments were stained with ethidium bromide, visualized under UV illumination (Hoefer UV-25) 
and the gel image was retrieved by using EDAS program (Electrophoresis Documentation and Analysis System 120 - Kodak Digital Science 1D).

PCR amplification of 5S rDNA repeats from shark specimens generated a distinct agarose gel fragment pattern for each analyzed species. We did not find variation among different samples of the same species (Figure 2). Fragment sizes ranged from approximately $130 \mathrm{bp}$ for the minor band in the blacktip shark C. limbatus to approximately $1,000 \mathrm{bp}$ for the largest band in the mako I. oxyrinchus, and the unique band in the bigeye thresher $A$. superciliosus. The tiger shark G. cuvier showed a single band of approximately $520 \mathrm{bp}$ band. The bands for the scalloped hammerhead $S$. lewini were approximately $220 \mathrm{bp}$ and $480 \mathrm{bp}$, respectively. I. oxyrinchus showed two r amplified fragments of approximately $300 \mathrm{bp}$ and $400 \mathrm{bp}$. The requien sharks, genus Carcharhinus, exhibited very distinct PCR band patterns, with one, two, three or four fragments in agarose gels. The blacknose shark C. acronotus presented only a single band of approximately $450 \mathrm{bp}$, while fragments of approximately $130 \mathrm{bp}$ and $520 \mathrm{bp}$ were obtained for C. limbatus. The dusky shark C. obscurus and the bull shark C. leucas, had similar three bands of approximately 450, 500 and $540 \mathrm{bp}$, with an additional band of $230 \mathrm{bp}$ in C. leucas. The distinct amplified fragment patterns of the analyzed shark species, detected by agarose gel electrophoresis, reflect a high variability in the 5S rDNA genomic architecture. This is probably due to major differences in the sharks' NTS organization, since the coding region was found to be conserved in other cartilaginous fishes (Pasolini et al., 2006). Nucleotide sequence analyses based on the NTS have shown that the great variability found in this region can be due to insertions/deletions, minirepeats, and pseudogenes

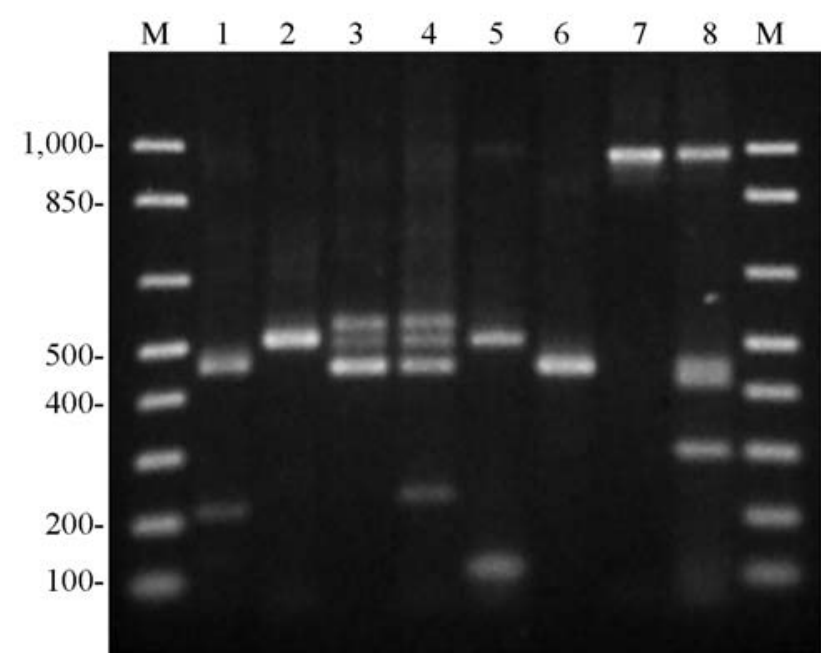

Figure 2 - Agarose electrophoresis profiles of $5 \mathrm{~S}$ rDNA-PCR products of Sphyrna lewini (1), Galeocerdo cuvier (2), Carcharhinus obscurus (3), Carcharhinus leucas (4), Carcharhinus limbatus (5), Carcharhinus achronotus (6), Alopias superciliosus (7), Isurus oxynchus (8). M, molecular mass marker in bp.
(Nelson and Honda, 1985; Leah et al., 1990; Sajdak et al., 1998).

The NTS regions seem to be subject to intense evolution, which makes this region an important source for studies concerning the organization and evolution of multigene families and genomes and also as markers to trace recent evolutionary events. Previous studies have shown the presence of different $5 \mathrm{~S}$ rDNA arrays in the fish genome (Martins and Wasko, 2004). Similarly, the multiple bands detected for some of the analyzed shark species suggest the presence of different $5 \mathrm{~S}$ rDNA classes also among cartilaginous fishes. One interesting characteristic of the $5 \mathrm{~S}$ rDNA repeats is the tendency of homogenization of the different copies that are arrayed in the same cluster, which can differ extensively from the copies of a second $5 \mathrm{~S}$ cluster (Martins and Wasko, 2004). Multigene families are thought to evolve according to homogenization processes governed by molecular drive and concerted evolution, resulting in sequence similarity of the repeat units that is greater within than between species (Dover, 1986; Elder and Turner, 1995). This process was clearly observed in the organization of the 5S rDNA in the Nile tilapia Oreochromis niloticus (Martins et al., 2002) and in the South American species of the genus Leporinus (Martins and Galetti, 2001).

Particularly among fishes, different NTS lengths have been used as efficient genetic markers for sex identification and for inspection programs that intend to access species, hybrids, or identity of smoked products. In the rainbow trout (Oncorhynchus mykiss), chromosome hybridization analyses on male and female metaphase spreads revealed a 5S rDNA chromosome sex-specific pattern (Morán et al., 1996). PCR amplified products of 5S rDNA clearly discriminate the Atlantic salmon (Salmo salar), the brown trout (Salmo truta), and their hybrids (Pendás et al., 1995), and also several Neotropical fish species of the genus Brycon (Wasko et al., 2001). PCR was also applied in the identification of the flatfishes Solea solea and Reinhardtius hippoglossoides (Céspedes et al., 1999) and for the identification of smoked fillets of salmon, rainbow trout, and bream (Brama raii) (Carrera et al., 2000). The present results also demonstrated that 5S rDNA repeats represent good markers for shark species identification at several taxonomic levels.

Previous molecular analyses on shark species discrimination were based on a multiplex PCR assay using both nuclear (ribosomal internal transcribed spacer 2) and mitochondrial (cytochrome $b$ ) loci simultaneously (Pank et al., 2001; Shivji et al., 2002; Chapman et al,. 2003; Shivji et al., 2005; Abercrombie et al., 2005; Clarke et al., 2006), or on mitochondrial gene sequences (Heist and Gould, 1999; Greig et al., 2005). However, these approaches are not only time consuming but also expensive. The PCR amplification of $5 \mathrm{~S}$ rDNA repeats and agarose gel electrophoresis analysis showed to be a simple routine and low cost methodology to achieve shark species identification. Moreover, this prac- 
tice can be used to corroborate the usual morphometric and morphological identification of these animals (Last and Stevens, 1994; Naylor and Marcus, 1994) and can be also used to recognize "cryptic" species, like those of the genus Carcharhinus, in which morphological identification can not be easily done.

Particularly in fishery management and conservation, the 5S rDNA PCR approach does not require intensive or expensive labor to be implemented. Additionally, such technology could be applied to body parts that are commonly sold in markets with the generic name of "shark meat", allowing assessment of shark catch and trade on a species-specific basis to detect potential overexploitation of individual species.

\section{Acknowledgments}

The authors are grateful to Mr. Nestor Rago from Instituto de Investigaciones Agropecuarias for his help during sample collection in Venezuela and Mr. Nelson Dreux, from Instituto de Pesca (Santos, São Paulo, Brazil) for donation of several specimens. This work was supported by Fundação de Amparo à Pesquisa do Estado de São Paulo (FAPESP), Conselho Nacional de Desenvolvimento Científico e Tecnológico (CNPq), and Coordenação de Aperfeiçoamento de Pessoal do Ensino Superior (CAPES).

\section{References}

Abercrombie DL, Clarke SC and Shivji MS (2005) Global-scale genetic identification of hammerhead sharks: Application to assessment of the international fin trade and law enforcement. Conserv Genet 6:775-788.

Asensio L, Gonzalez I, Fernandez A, Cespedes A, Rodriguez MA, Hernandez PE, Garcia T and Martin R (2001) Identification of Nile perch (Lates niloticus), grouper (Epinephelus guaza), and wreck fish (Polyprion americanus) fillets by PCR amplification of the 5S rDNA gene. J AOAC Int 84:777-781.

Aranishi F (2005) PCR-RFLP analysis of nuclear nontranscribed spacer for mackerel species identification. J Agric Food Chem 53:508-511.

Baum JK and Myers RA (2004) Shifting baselines and the decline of pelagic sharks in the Gulf of Mexico. Ecol Lett 7:135145.

Baum JK, Myers RA, Kehler DG, Worm B, Harley SJ and Doherty PA (2003) Collapse and conservation of shark populations in the northwest Atlantic. Science 299:389-392.

Bonfil R (1994) Overview of World Elasmobranch Fisheries. FAO Fisheries Technical Paper n. 341,119 pp.

Carrera E, Garcia T, Céspedes A, Gozález I, Fernández A, Asensio LM, Hernández PE and Martin R (2000) Differentiation of smoked Salmo solar, Onconhynchus mykiss and Brama raii using the nuclear marker $5 \mathrm{~S}$ rDNA. Int J Food Sci Technol 35:401-406.

Castro J, Pardo BG, Sánchez L and Martínez P (1999) rDNA RFLPs as genetic markers for resource management in brown trout. J Fish Biol 55:221-225.
Céspedes A, Garcia T, Carrera E, Gonzalez I, Fernandez A, Hernandez PE and Martin R (1999) Identification of sole (Solea solea) and Greenland halibut (Reinhardtius hippoglossoides) by PCR amplification of the 5S rDNA gene. J Agric Food Chem 47:1046-1050.

Chapman DD, Abercrombie DL, Douady CJ, Pikitch EK, Stanhope MJ and Shivji MS (2003) A streamlined, bi-organelle, multiplex PCR approach to species identification: Application to global conservation and trade monitoring of the great white shark, Carcharodon carcharias. Conserv Genet 4:415-425.

Clarke SC, Magnussen JE, Abercrombie DL, McAllister MK and Shivji MS (2006) Identification of shark species composition and proportion in the Hong Kong shark fin market based on molecular genetics and trade records. Conserv Biol 20:201-211.

Cortés E (2002) Incorporating uncertainty into demographic modeling: Application to shark populations and their conservation. Conserv Biol 16:1-15.

Dover GA (1986) Linkage disequilibrium and molecular drive in the rDNA gene family. Genetics 122:249-252.

Elder Jr JF and Turner BJ (1995) Concerted evolution of repetitive DNA sequences in eukaryotes. Q Rev Biol 70:277-320.

Greig TW, Moore MK and Woodley CM (2005) Mitochondrial gene sequences useful for species identification of western North Atlantic Ocean sharks. Fish Bull 103:516-523.

Heist EJ and Gold JR (1999) Genetic identification of sharks in the US Atlantic large coastal shark fishery. Fish Bull 97:5361.

Kotas JE, Rocha-Gamba M da, Conolly PC, Hostim-Silva M, Mazzoleni RC and Pereira J (1995) Gillnet Activities in Southern Brazil. Instituto Brasileiro do Meio Ambiente e dos Recursos Naturais Renováveis, Itajaí, 48 pp.

Last PR and Stevens JD (1994) Sharks and rays of Australia. Commonwealth Scientific and Industrial Research Organization Publishing, Melbourne, 513 pp.

Lavery S (1992) Electrophoretic analysis of phylogenetic relationships among Australian carcharhinid sharks. Aust J Mar Freshw Res 43:97-108.

Leah R, Frederiksen S, Engberg J and Sorensen PD (1990) Nucleotide sequence of a mouse 5S rRNA variant gene. Nucleic Acids Res 18:7441-7441.

Long EO and David IB (1980) Repeated genes in eukaryotes. Annu Rev Biochem 49:727-764.

Martins C and Galetti Jr PM (2001) Organization of 5S rDNA in species of the fish Leporinus: Two different genomic locations are characterized by distinct nontranscribed spacers. Genome 44:903-910.

Martins C and Wasko AP (2004) Organization and evolution of 5S ribosomal DNA in the fish genome. In: Williams CR (ed) Focus on Genome Research. Nova Science Publishers, Hauppauge, pp 335-363.

Martins C, Wasko AP, Oliveira C, Porto-Foresti F, Parise-Maltempi PP, Wright JM and Foresti F (2002) Dynamics of 5S rDNA in the tilapia (Oreochromis niloticus) genome: Repeat units, inverted sequences, pseudogenes and chromosome loci. Cytogenet Genome Res 98:78-85.

Martins C, Oliveira C, Wasko AP and Wright JM (2004) Physical mapping of the Nile tilapia (Oreochromis niloticus) genome by fluorescent in situ hybridization of repetitive DNAs to metaphase chromosomes-a review. Aquaculture 231:37-49. 
Móran P, Martínez JL, Garcia-Vásquez E and Pendás AM (1996) Sex linkage of 5S rDNA in rainbow trout (Oncorhynchus mykiss). Cytogenet Cell Genet 75:145-150.

Mullis KB and Faloona FA (1987) Specific synthesis of DNA in vitro via polymerase-catalyzed chain reaction. Methods Enzymol 155:335-350.

Musick JA, Burgess GH, Camhi M, Cailliet G and Fordham S (2000) Management of sharks and their relatives (Elasmobranchii). Fisheries 25:9-13.

Naylor GJP and Marcus LF (1994) Identifying isolated shark teeth of the genus Carcharhinus to species: Relevance for tracking phyletic change through the fossil record. Am Mus Novit 94:1-53.

Nelson DW and Honda BM (1985) Genes coding for 5S ribosomal RNA of the nematode Caenorhabditis elegans. Gene 38:245-251.

Pank M, Stanhope M, Natanson L, Kohler N and Shivji M (2001) Rapid and simultaneous identification of body parts from the morphologically similar sharks Carcharhinus obscurus and Carcharhinus plumbeus (Carcharhinidae) using multiplex PCR. Mar Biotechnol 3:231-240.

Pasolini P, Costagliola D, Rocco L and Tinti F (2006) Molecular organization of 5S rDNA in Rajidae (Chondrichthyes): Structural features and evolution of piscine 5S rRNA genes and nontranscribed intergenic spacers. J Mol Evol 62:564574.

Pendás AM, Morán P, Martinez JL and Garcia-Vazquez E (1995) Application of 5S rDNA in Atlantic salmon, brown trout, and in Atlantic salmon x brown trout hybrid identification. Mol Ecol 4:275-276.

Perez J and Garcia-Vazquez E (2004) Genetic identification of nine hake species for detection of commercial fraud. J Food Prot 67:2792-2796.

Rocco L, Costagliola D, Fiorillo M, Tinti F and Stingo V (2005) Molecular and chromosomal analysis of ribosomal cistrons in two cartilaginous fish, Taeniura lymma and Raja montagui (Chondrichthyes, Batoidea). Genetica 123:245253.

Sajdak SL, Reed KM and Phillips RB (1998) Intraindividual and interspecies variation in the $5 \mathrm{~S}$ rDNA of Coregonid fish. $\mathrm{J}$ Mol Evol 46:680-688.

Sambrook J and Russel DW (2001) Molecular Cloning: A Laboratory Manual. 3rd ed. Cold Spring Harbor Laboratory Press, Cold Spring Harbor.

Shivji MS, Clarke S, Pank M, Natanson L, Kohler N and Stanhope M (2002) Genetic identification of pelagic shark body parts for conservation and trade monitoring. Conserv Biol 16:1036-1047.

Shivji MS, Chapman DD, Pikitch EK and Raymond PW (2005) Genetic profiling reveals illegal international trade in fins of the great white shark, Carcharodon carcharias. Conserv Genet 6:1035-1039.

Simpfendorfer CA, Donohue K and Hall NG (2000) Stock assessment and risk analysis for the whiskery shark (Furgaleus macki [Whitley]) in southwestern Australia. Fish Res 47:117.

Sotelo CG, Pineiro C, Gallardo JM and Perezmartin RI (1993) Fish species identification in seafood products. Trends Food Sci Tech 4:395-401.

Vooren CM (1997) Demersal elasmobranchs. In: Seeling U, Odebrecht $\mathrm{C}$ and Castello JP (eds) Subtropical Convergence Environments: The Coast and Sea in the Southwestern Atlantic. Springer Verlag, New York, pp 141-146.

Wasko AP, Martins C, Wright JM and Galetti Jr PM (2001) Molecular organization of 5S rDNA in fishes of the genus Brycon. Genome 44:893-902.

Wegnez M, Denis H, Mazabraud A and Clerot JC (1978) RNA accumulation during oogenesis of the dogfish Scyliorhinus caniculus. Biochemical research on oogenesis. Dev Biol 62:99-111.

Associate Editor: Pedro Manoel Galetti Junior 